\title{
Antimicrobial activity of certain herbal plant extracts against pathogenic microbes and their application in sterilized milk medium
}

\author{
Farzana Siddique ${ }^{1}$, Aaayisha Latif ${ }^{2}$, Muhammad Arshad ${ }^{3}$ and Mushtaq \\ Hussain Lashari ${ }^{4}$ \\ 1. Institute of Food Science and Nutrition, University of Sargodha-Pakistan \\ 2. Department of Food Technology, PMAS- Arid Agriculture University, Rawalpindi-Pakistan \\ 3. Department of Zoology, University of Sargodha-Pakistan \\ 4. Department of Zoology, The Islamia University of Bahawalpur-Pakistan \\ *Corresponding author's email: mushtaqlashary@gmail.com
}

Citation

Farzana Siddique, Aaayisha Latif, Muhammad Arshad and Mushtaq Hussain Lashari. Antimicrobial activity of certain herbal plant extracts against pathogenic microbes and their application in sterilized milk medium. Pure and Applied Biology. Vol. 10, Issue 2 pp378-387. http://dx.doi.org/10.19045/bspab.2021.100041

\begin{tabular}{llll}
\hline \hline Received: 07/03/2020 & Revised: 01/10/2020 & Accepted: 02/10/2020 & Online First: 08/10/2020 \\
\hline \hline
\end{tabular}

\section{Abstract}

The antibacterial activities of the rosemary, oregano, clove and cinnamon extracts against Listeria monocytogenes, Bacillus subtilis, Escherichia coli, Staphylococcus aureus and Pseudomonas aeruginosa were evaluated in agar diffusion test medium and in sterilized milk medium at $37{ }^{\circ} \mathrm{C}$ within $24 \mathrm{hr}$ time interval. All tested herbal extracts exhibited an inhibitory effect against pathogens. Gram-negative bacteria $E$. coli and $P$. aeruginosa were less susceptible to the inhibitory activity of all herbal extracts used in the experiment as compared to Grampositive bacteria Staph. aureus, L. monocytogens and B. subtilis in nutrient agar medium as well as in sterilized milk medium. Oregano showed significant effect against all pathogens as compared to clove, cinnamon and rosemary. Whereas, results from rosemary showed significant decrease inmicrobial activity against pathogens as compared to other tested herbal extracts. These results suggest the prospect of using these herbal extracts in milk and milk products as natural antimicrobials.

Keywords: Antimicrobial activity; Herbs; Pathogens; Sterilize milk

\section{Introduction}

Prevention of food spoilage and food poisoning pathogens is usually achieved by use of chemical preservatives which have negative impacts including: human health hazards of the chemical applications, chemical residues in food \& feed chains and acquisition of microbial resistance to the used chemicals. Because of such concerns, the necessity to find a potentially effective, healthy safer and natural alternative preservative is increased. Within this text, Plant extracts have been used to control pathogens causing diseases and spoilage to milk and milk products. Bacterial contamination is one of the major reasons that causes loss of quality of food and reduce shelf life of food products during 
transportation, refrigeration and storage [1]. Many plants have antimicrobial action due to their vital oil elements present in their extracts. Several scientists have described the antimicrobial action of vital oils from oregano, thyme, sage, rosemary, clove, cinnamon, garlic, cayenne, pepper, celery, chives, ginger, savory and onion against microbes [2-4]. Various naturally derived constituents derived from herbs and spices are utilized as preservatives such as essential oils, flavonoids, phenolic compound, microbial metabolites and antimicrobial constituents of other foods that possess the preserving action.

The structural and functional groups of the oils showed a significant role as antimicrobial action $[5,6]$. Some main antimicrobial components have been documented as aldehydes, ketones, polyphenols, ethers, alcohols, and hydrocarbons [7]. Some spices oils are utilized in food industry as natural food preservatives. It possesses important characteristics to inhibit wide spectrum of pathogens due to presence of antimicrobial components [8, 9]. These natural preservatives are gaining significance in recent years as they have little or no harmful effects. Greater consumer responsiveness and awareness about synthetic chemical additives directed researchers and food processors to look for natural food preservatives with a wide series of antimicrobial agent.
Milk is mostly produced in small units in remote areas. It gets spoiled in short time due to its perishable nature and conventional unhygienic handling practices mainly in summer season. Raw or processed milk is a good medium for growth of a number of microbes and consumption of the spoiled product results into infections/ intoxications in consumers $[10,11]$. Dairy cows suffering from sub clinical or clinical mastitis are source of direct entry of microbes into raw milk from the farm environment, mostly the water source and utensils used for the storage of milk on dairy farm or for the duration of transportation. The dairy industry is developing minimum processing techniques $[12,13]$, that can be used to extend the shelf of fluid milk. Soto preserve milk there is need to develop biopreservative instead of chemical preservatives by utilization of plant extracts. The current study is conducted to evaluate the antibacterial activities of the plant extracts of rosemary, oregano, clove and cinnamon extracts against Listeria monocytogenes, Bacillus subtilis, Escherichia coli, Staphylococcus aureus and Pseudomonas aeruginosa in through agar diffusion test medium and milk medium.

\section{Materials and methods} Herbal plant samples

The description of herbal plants used in this study is given in (Table 1). Rosemary, clove, cinnamon and oregano were collected from local market, Islamabad, Pakistan.

Table 1. Herbal plants used in the experiment

\begin{tabular}{|c|c|c|}
\hline Common name of Plants & Botanical name & Plant parts used \\
\hline Rosemary & Rosmarinus officinalis $L$. & Leaf \\
\hline Clove & Eugenia caryophylata & Bud \\
\hline Cinnamon & Cinnamomum cassia & Bark \\
\hline Oregano & Origanum vulgare & Leaf \\
\hline
\end{tabular}

Preparation of aqueous extracts of rosemary, clove, cinnamon and oregano
Extraction was carried out using method described by [14] with some modification. $100 \mathrm{~g}$ crushed powder from each part of 
plant was individually immersed using500 $\mathrm{ml}$ of 95 percent ethanol taken in a flask of 1 liter capacity, the flask was kept shaking for 4 days at $150 \mathrm{rpm}$ and room temperature. The solutions were first passed through a muslin cloth and filtrate collected were filtered again by using a filter paper i.e. Whatman's filter paper No.1 to achieve a particle free solution. The filtrates were evaporated using rotary evaporator and kept at $-80^{\circ} \mathrm{C}$ to be frozen before subjecting to freeze drying. The prepared aqueous extracts were collected in sample bottles and stored in refrigerator at $4{ }^{\circ} \mathrm{C}$ before using.

\section{Microbial inoculum preparation}

Strains of milk pathogenic bacteria Listeria monocytogenes, Bacillus subtilis, Escherichia coli, Staphylococcus aureus and Pseudomonas aeruginosa were obtained from the culture collection of laboratory of Microbiology, department of Food Technology, PMAS Arid Agriculture University Rawalpindi. During the entire research period, the fresh bacterial inoculums were cultured and used. The nutrient broth (NB) was prepared and $5 \mathrm{ml}$ was poured into each tube and sterilized. Inoculation in tubes was done by picking few colonies of tested bacteria with help of sterilized loop. The incubation of tubes was carried out at $37^{\circ} \mathrm{C}$ for 24 hours. The presence of inhibition zones were measured by Vernier caliper, recorded and considered as indication for antibacterial activity.

\section{Testing on agar well diffusion}

Antibacterial assay of plant extracts was performed by agar well diffusion methodas described earlier [15]. In this well-known procedure, agar plates were inoculated with standardized $0.1 \mathrm{ml}$ of in column of test microorganism. Then filter paper discs containing $0.02 \mathrm{ml}$ of plant extract was poured in to well. Petri dishes were incubated under suitable conditions. Generally, antimicrobial agent diffuses into agar and inhibits germination and growth of test bacterium and then the diameters of inhibition growth zones were measured.

\section{Testing on isolated milk pathogenic strains}

The sterilized milk medium was inoculated at the rate of initial inoculum of 3.5, 5.54, $4.47,4.3$ and $7.62 \log \mathrm{CFU} / \mathrm{ml}$ of $L$. monocytogen, Staph. aureus, B. subtilis, E. coliand $P$. aeruginosa respectively. The growth of microbes was observed at $37^{\circ} \mathrm{C}$ for $24 \mathrm{~h}$ in sterilized milk medium supplemented with clove, cinnamon, oregano and rosemary extracts at concentration of $5 \%(\mathrm{v} / \mathrm{v})$.

\section{Statistical analysis}

The data obtained throughout the entire research was statistically analyzed using analysis of variance (ANOVA) by the help of Statistics 8.1 software to compare the means. Tukey's Test was used for means comparison. Graphical representation of data was done on Microsoft excel.

\section{Results and Discussion}

Antimicrobial screening of herbal extracts using agar well diffusion method

In general, the obtained data in the present study showed that extracts of rosemary, cinnamon, clove and oregano confirmed the antibacterial activity against Staph. aureus, L. monocytogens, B. subtilis, E. coli and $P$. aeruginosa in agar well diffusion method. (Table 2) reviewed that inhibition of the oregano extract was stronger than that of the others, showing inhibition zones ranging from 23-30 mm. On the other hand rosemary extract showed less inhibitory effect with 15-22 $\mathrm{mm}$ diameter inhibition zones against all pathogenic bacteria compared to the same levels of oregano, clove and cinnamon extracts. Gram-negative bacteria $E$. coli and $P$. aeruginosa were less susceptible to the inhibitory activity of all herbal extracts used in the experiment as compared to Gram-positive bacteria Staph. aureus, L. monocytogens and B. subtilis. Clove and cinnamon showed bactericidal 
effect with inhibition zones, diameter 18$27 \mathrm{~mm}$ and $17-25 \mathrm{~mm}$, respectively against all four pathogenic bacteria.

Previous researchers confirmed that natural antimicrobial compounds present in plants were found to possess antimicrobial activity. In order to use plants to control pathogens in milk products, it is essential that investigation of antibacterial activity of plant extracts carried out against pathogens [16]. S. aureus, P. aeruginosa, E. coli as were inhibited with extracts of cinnamon, cloves, and cumin with inhibition zones ranges between $<10$ and $>30 \mathrm{~mm}$ estimated by the disc diffusion method. Researchers screened out the antimicrobial activity and total phenolic contents of dietary spices and medicinal herbs extracts including cinnamon, rosemary, oregano and clove against five foodborne bacteria (B. cereus, L. monocytogenes, S. aureus, E. coli, and Salmonella anatum [16].

Table 2. Antibacterial properties of rosemary, cinnamon, clove and oregano extracts against pathogenic strains in agar well diffusion method.

\begin{tabular}{|c|c|c|c|c|c|}
\hline \multicolumn{7}{|c|}{ Inhibition zone diameter $(\mathbf{m m})$ against* } \\
\hline Treatment & L. monocytogens & Staph. aureus & E. coli & B. subtilis & P. aeruginosa \\
\hline Control & $\mathbf{0}$ & $\mathbf{0}$ & $\mathbf{0}$ & $\mathbf{0}$ & $\mathbf{0}$ \\
\hline Rosemary & $21.00 \pm 0.46$ & $22.50 \pm 0.20$ & $19.53 \pm 0.31$ & $21.00 \pm 0.40$ & $15.50 \pm 0.20$ \\
\hline Clove & $23.00 \pm 0.95$ & $24.00 \pm 0.30$ & $20.90 \pm 0.70$ & $27.00 \pm 0.40$ & $18.23 \pm 0.72$ \\
\hline Cinnamon & $24.00 \pm 0.42$ & $25.0 \pm 0.1$ & $18.07 \pm 0.43$ & $22.83 \pm 0.21$ & $17.00 \pm 0.42$ \\
\hline Oregano & $25.40 \pm 0.34$ & $27.5 \pm 0.31$ & $28.00 \pm 0.28$ & $31.87 \pm 0.85$ & $21.00 \pm 0.42$ \\
\hline
\end{tabular}

*well diameter, $6 \mathrm{~mm}$, included and results presented as a mean value of three replicates

\section{Antimicrobial effects of herbal extracts against pathogenic strains in sterilized milk medium}

Antibacterial behavior of clove, cinnamon, oregano and rosemary extracts against of $L$. monocytogen, Staph. aureus, B.subtilis, P. aeruginosa and $E$. coli was shown in (Figs. 1-5), respectively. The sterilized milk medium was inoculated at the rate of initial inoculums of $3.5 \mathrm{log} \mathrm{CFU} / \mathrm{ml}, 5.54 \mathrm{log}$ $\mathrm{CFU} / \mathrm{ml}, 4.47 \log \mathrm{CFU} / \mathrm{ml}, 7.62 \log \mathrm{CFU} / \mathrm{ml}$ and $4.3 \log \mathrm{CFU} / \mathrm{ml}$ of L. monocytogens, Staph. aureus, B. subtilis, P. aeruginosa and E. coli respectively, supplemented with clove, cinnamon, oregano and rosemary extracts at concentration of $5 \%$ (v/v).Concentration of plant extracts utilized in foods could vary from 2 to 100 fold of that used in the in vitro assays depending on the herb type and food system used $[17,18]$. In sterilized milk medium the addition of herbal extracts led to reduction of the viability of all five pathogens. Cinnamon and clove showed statistically similar results in case of L. monocytogens and B. subtilis and reduction was upto $2.5 \mathrm{log}$ cycle and 2 log cycles for both organisms, respectively. Reduction of $S$. aureusby cinnamon and clove was upto $3 \mathrm{log}$ cycles and $2.5 \mathrm{log}$ cycles respectively. $P$. aeruginosaand $E$. coli reduced upto 2 log cycles by clove and upto $2.4 \log$ cycles by cinnamon. In the present study, the antimicrobial activity exhibited by the cinnamon extract against different pathogenic strains of bacteria may be due to the presence of its active aromatic aldehydic compound i.e. cinnamaldehyde.

Cinnamon bark contain $50.5 \%$ cinnamaldehyde which is highly electronegative and interferes in biological processes involving electron transfer and react with nitrogen containing components (proteins and nucleic acids) and therefore reduce the growth of the microorganisms [19]. It also cause energy deprivation in the cell which leads to microbial cell death due 
to inhibition of the amino acid decarboxylation activity in the cell. Therefore cinnamaldehyde was proved as an active agent against many pathogenic bacteria [20]. On the other hand, strong antibacterial effects of clove and its antimicrobial activity is due to its principal active constituent's eugenol, eugenol acetate

carvacrol and thymol that are phenylpropanoides. Eugenol having phenolic structure is highly active against the pathogens $[21,22]$. Mixtures of clove and cinnamon essential oils inhibited the growth of L. monocytogenes and E. coli in pasteurized milk.

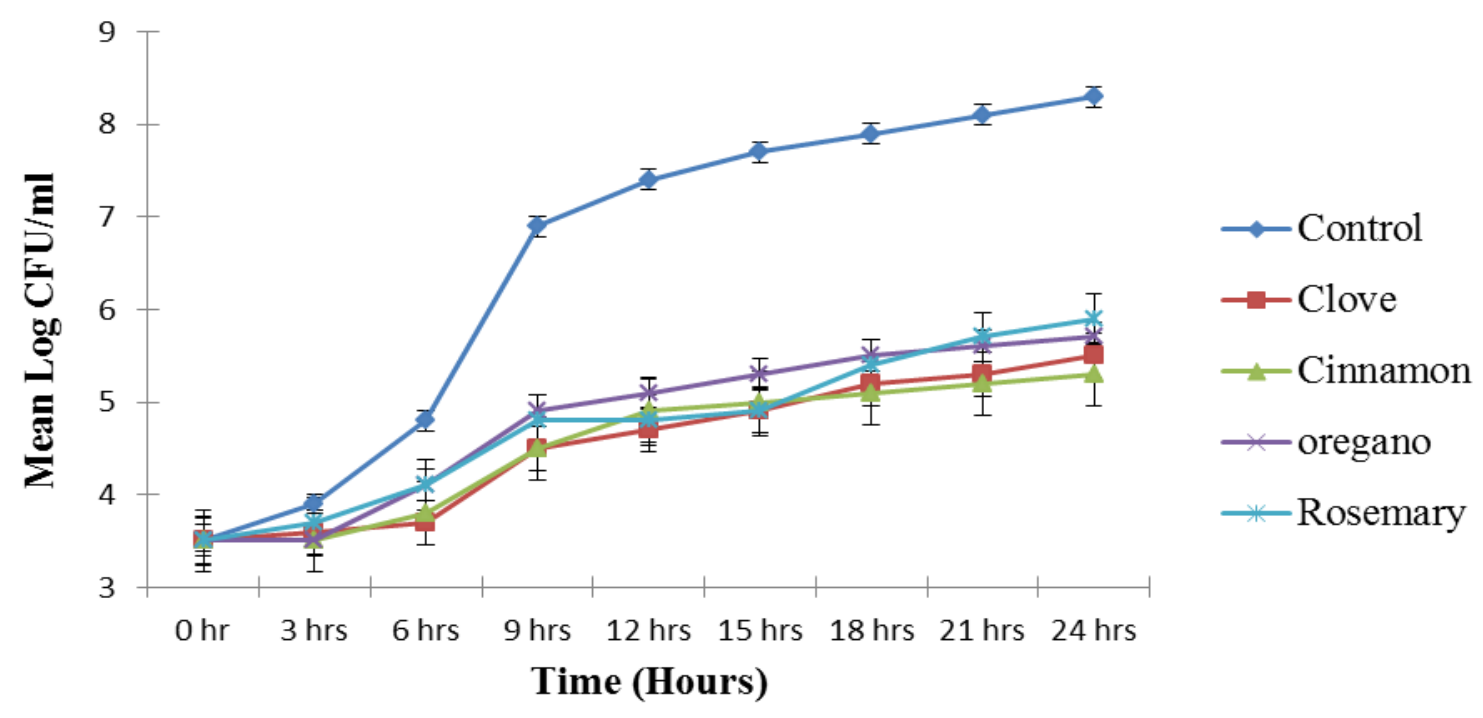

Figure 1. Behavior of $L$. monocytogenes in sterilized milk incubated at $37^{\circ} \mathrm{C}$ for $24 \mathrm{hr}$ with addition of plant extracts

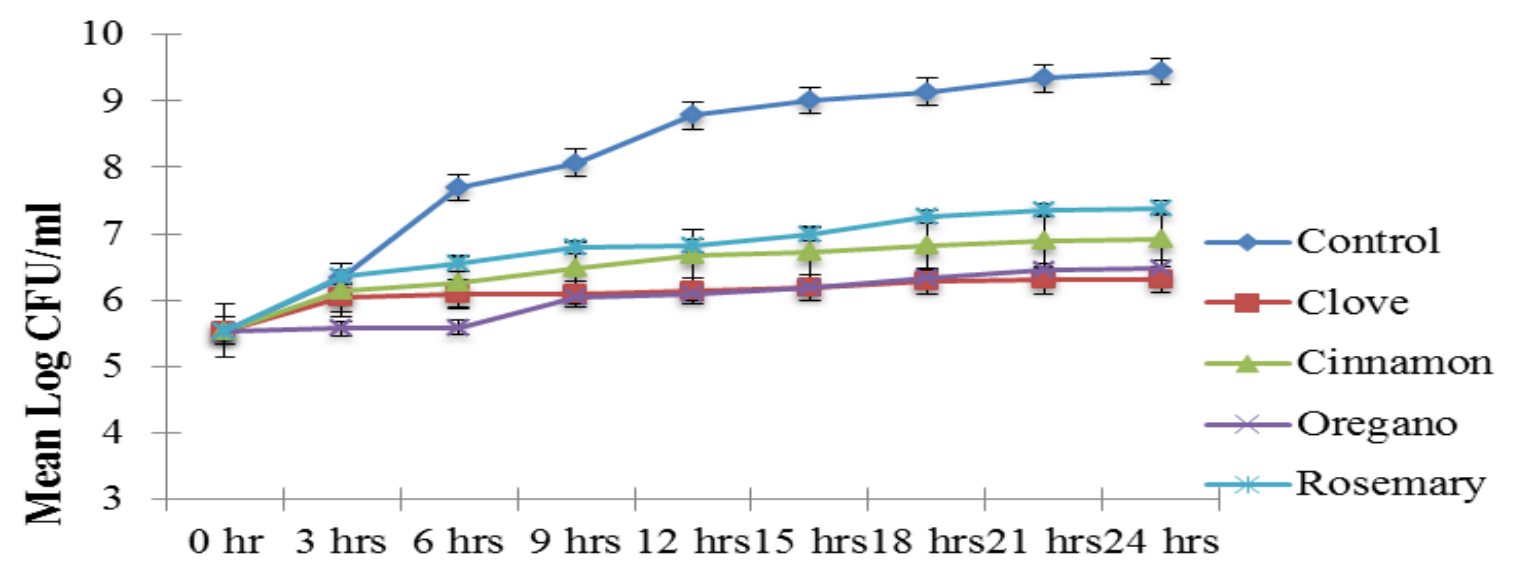

Time(Hours)

Figure.2. Behavior of $S$. aureusin sterilized milk incubated at $37^{\circ} \mathrm{C}$ for $24 \mathrm{hr}$ with addition of plant extracts 


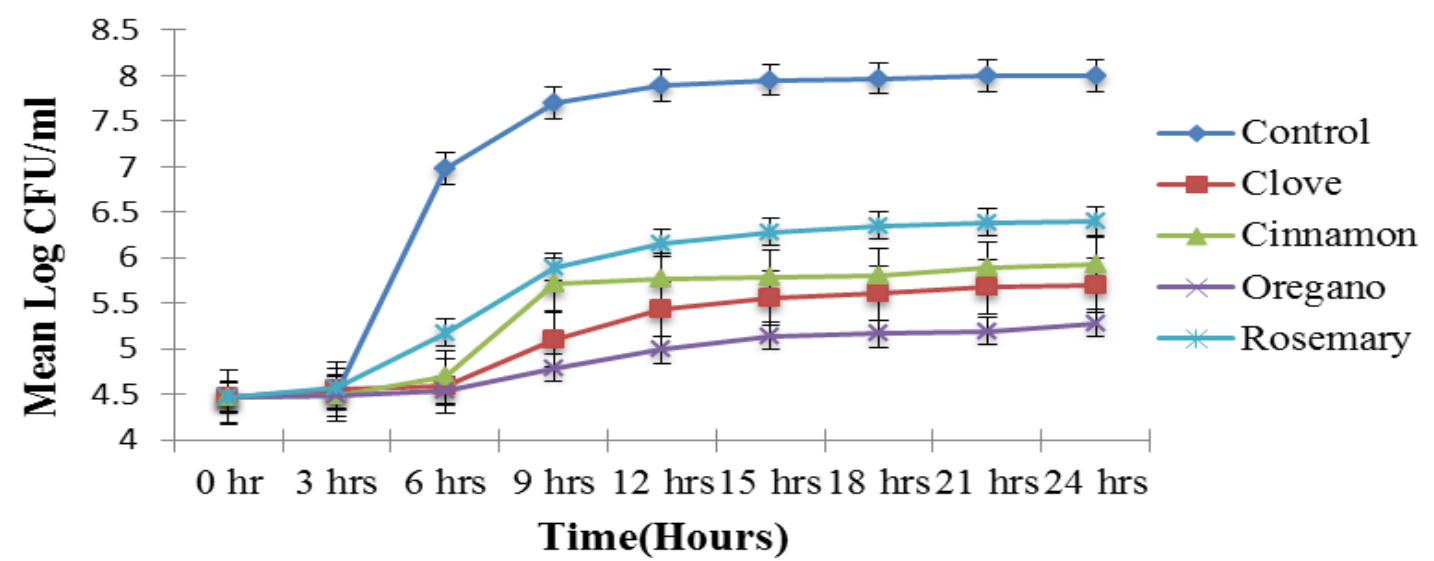

Figure 3. Behavior of $B$. subtilisin sterilized milk incubated at $37^{\circ} \mathrm{C}$ fo $24 \mathrm{hr}$ with addition of plant extracts

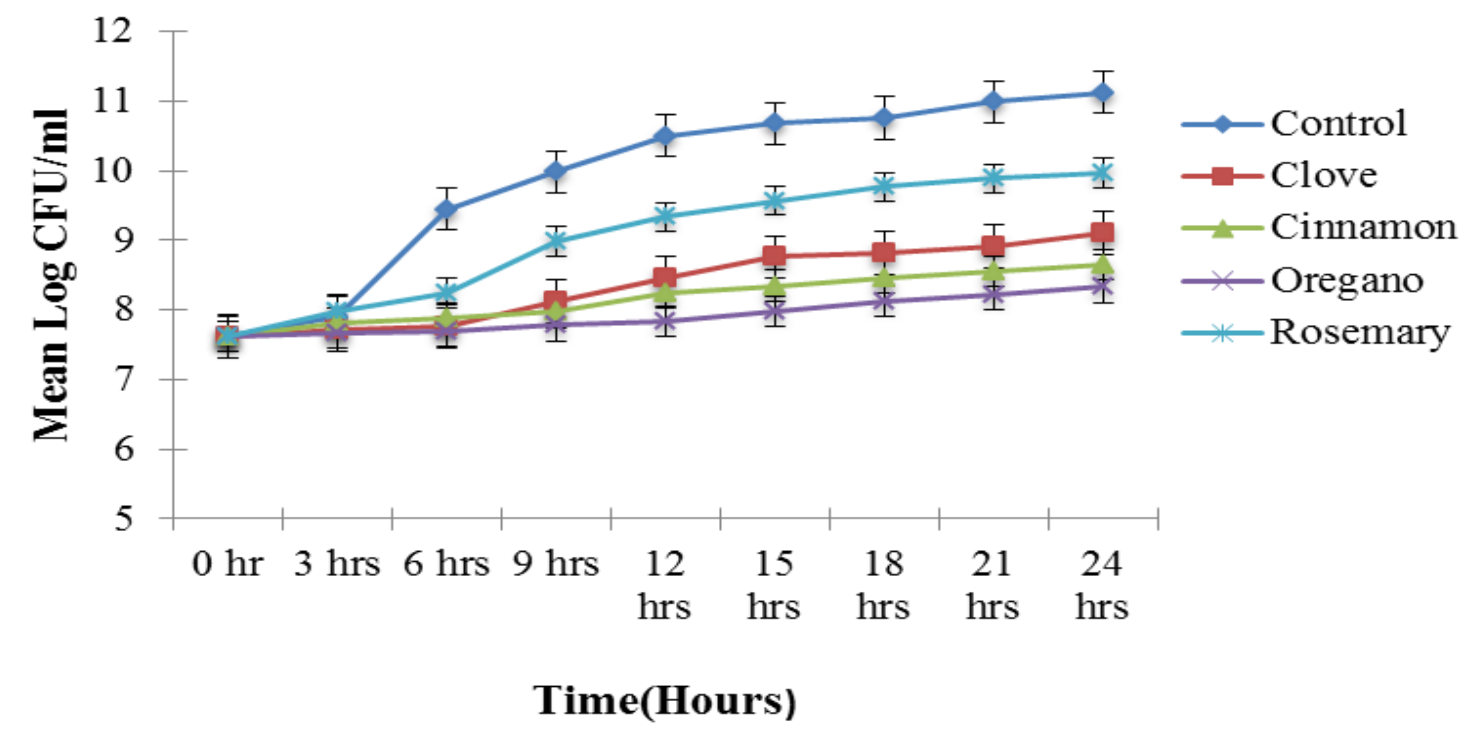

Figure 4. Behavior of $P$. aeruginosa in sterilized milk incubated at $37^{\circ} \mathrm{C}$ for $24 \mathrm{hr}$ with addition of plant extracts 


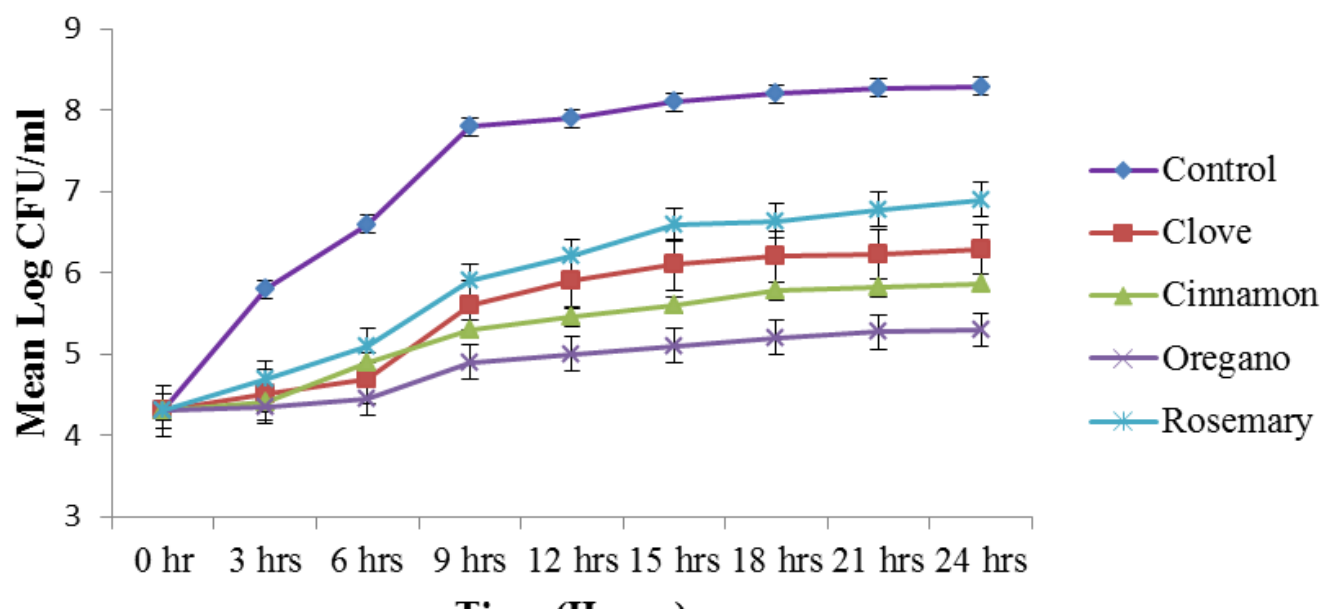

Time (Hours)

Figure 5. Behavior of E.coliin sterilized milk incubated at $37^{\circ} \mathrm{C}$ for $24 \mathrm{hr}$ with addition of plant extracts

Reduction of L. monocytogens, Staph. aureus, B. subtiliswasupto 2- 2.3 log cycles by rosemary while $P$. aeruginosa and $E$. coli decreased upto1.0 log cycles. Oregano has more pronounced effect than all other herbal extracts as it reduced the all pathogens upto 2.7-3 log cycles showing greater antibacterial activity than all other herbal extracts. Rosmarinic acid and carnosic acid were considered to be the most effective antimicrobial compounds against bacterial species present in the rosemary plant. It was found by [23], that ethanol extract of rosemary exhibited wide-ranging activity against Gram-positive and gram-negative bacteria as compared to methanolic and aqueous extract. Antimicrobial property of oregano exhibited in the current study is due to its major active component carvacrol. Other constituents of oregano alpha pinene, linalol, gamma cariofilene, canfor, rhocymenene, limonene and thymol also play some role in its antibacterial activity [24] also confirmed the antibacterial activity of oregano against food borne pathogens.
The reduction in the number of $L$. monocytogens, Staph. aureus and B. subtilis, was more pronounced ( $\mathrm{P}>0.05)$ compared to the culture of $P$. aeruginosa and E. coli. Above results demonstrate that Grampositive bacteria was more sensitive to all herbal extracts than Gram-negative bacteria. This was in agreement with the earlier studies on other herbal extracts $[25,26]$. A possible reason for these observations may be due to the significant differences in the outer layers of Gram-negative and Grampositive bacteria. An outer membrane and a unique periplasmic space present in the Gram-negative bacteria while Gram-positive bacteria lack of these outer layers make it easy for herbal components to enter in cell [27]. Several researchers reported the antibacterial actions of herbs like, vervan, cinnamon, oregano, rosemary and savage carrots in culture media [28-32]. Plant oils exerted only a limited action in food substrates [33]. Reported that microbes were neither eradicated nor completely inhibited, while clove oil was able to restrict the 
propagation of L. monocytogenes in both milk and mutton.

\section{Conclusion}

The results of current study indicate that the use of these plant extracts in milk as natural antimicrobials. These herbs are utilized and consumed all over the world and have potential to be used as natural biopreservative to increase shelf life of food products. However, great potential of these four plants for utilization in milk as well as milk products as antimicrobial possibly increase the safety of the product during its shelf life, provided that the initial microbial load in the milk was low .For further research, different combination of plant extracts would be suggested and their synergistic effects would possibly enhance the bactericidal effect.

\section{Authors' contributions}

Conceived and designed the experiments: $\mathrm{F}$ Siddique, Performed the experiments: A Latif, Analyzed the data: M Arshad

Contributed materials/ analysis/ tools \& Wrote the paper: MH Lashari.

\section{Reference}

1. Fernandez LJ, Zhi N, Aleson CL, Perez AJA \& Kuri V (2004). Antioxidant and antibacterial activities of natural extracts: application in beef meatballs. Meat Sci 69: 371-380.

2. Cava R, Nowak E, Taboada A \& MarinIniesta F (2007). Antimicrobial activity of clove and cinnamon essential oils against Listeria monocytogenes in pasteurized milk. J Food Prot 70(12): 2757-2763.

3. Celikel N \& Kavas G (2008). Antimicrobial properties of some essential oils against some pathogenic microorganisms. Czech J Food Sci 26: 174-181.

4. Al-Turki AI, El-Ziney MG \& Salam AMA (2008). Chemical and antibacterial characterization of aqueous extracts of oregano, marjoram, sage and licorice and their application in milk and labneh. J Food, Agr Envirn 6(1): 39-44.

5. Omidbeygi M, Barzegar M, Hamidi Z \& Naghdibadi H (2007). Antifungal activity of thyme, summer savory and clove essential oils against Aspergillus flavus in liquid medium and tomato paste. Food Control 18: 1518-1523.

6. Yesil CO, Hames KEE, Bedir E, Vardar SF, Ozek T \& Baser KHC (2007). Antimicrobial activities of methanol extracts and essential oils of Rosmarinus oicinalis, depending on location and seasonal variations. Food Chem 100: 553-559.

7. Erdogan C \& Daniel YCF (2004). Antimicrobial activity of spices. Food Science Institute Kansas State University Manhattan, Kansas, 66: 506.

8. Jirovetz L, Buchbauer G, Stoyanova, A SE, Georgiev V \& Damianova ST (2003). Composition, quality control, and antimicrobial activity of the essential oil of long-time stored dill (Anethumgraveolens L.) seeds from Bulgaria. J Agr Food Chem 51: 38543857.

9. Rusenova N and Parvanov P (2009). Antimicrobial activities of twelve essential oils against microorganisms of veterinary importance. Trakia J Sci 7: 37-43.

10. Murinda, SE, Nguyen LT, Man HM \& Almedia RA (2004). Detection of sorbitol negative and sorbitol-positive shiga toxin-producing Escherichia coli, Listeria monocytogenes, Campylobacter jejuniand Salmonella species in dairy farm environments. Foodborne Pathogens and Dis 1: 97-104.

11. Oliver SP, Jayarao BM \& Almedia RA (2005). Food borne pathogens in milk and the dairy environment food safety and public health implications. Foodborne Pathog Dis 2: 1115-1129. 
12. Leistner L (2000). Hurdle technology in the design of minimally processed foods, p. 13-27. In S. M. Alzamora, M. S. Tapia, and A. Lo'pezMalo (ed.), Minimally processed fruits and vegetables. Fundamental aspects and applications. Aspen Publishers, Gaithersburg, Md.

13. Goff HD \& Griffiths MW (2006). Major advances in fresh milk and milk products: fluid milk products and frozen dessert. J Dairy Sci 89: 1163-1173.

14. De N \& Ifeoma E (2002). Antibacterial effects of components of the bark extracts of neem (Agadiractaindica, A. Juss). Technol Dev 8: 23-28.

15. Saeed S, Naim A \& Tariq P (2006). In vitro antibacterial activity of peppermint. Pak J Bot 38(3): 869-872.

16. Nanasombat $S \&$ Lohasupthawee $P$ (2005). Antibacterial activity of crude ethanolic extracts and essential oils of spices against salmonellae and other entero-bacteria. Sci Technol J 5: 527535.

17. Karatzas AK, Kets EPW, Smid EJ and Bennik MHJ (2001). The combined action of carvacrol and high hydrostatic pressure on Listeria monocytogenes Scott. A. J Appl Microb 90: 463-469.

18. Ultee A \& Smid EJ (2001). Influence of carvacrol on growth and toxin production by Bacillus cereus. Int J Food Microb 68: 1561-1568.

19. Gupta C, Garg AP \& Uniyal RC (2008). Antibacterial activity of Amchur (dried pulp of unripe Mangifera indica) extracts on some food borne bacteria. $J$ Pharm Res 1: 54-57.

20. Wendakoon, C. N. and M. Sakaguchi. 1995. Combined effect of sodium chloride and clove on growth and biogenic amine formation of Enterobacter aerogenes in mackerel muscle extract. J Food Prot 56:410413.
21. Velluti A, Sanchis V, Ramos AJ, Egido J \& Marin S (2003). Inhibitory effect of cinnamon, clove, lemongrass, oregano and palmarose essential oils on growth and fumonisin B1 production by Fusarium proliferatum in maize grain. International J Food Microbiol 89: 145154.

22. Chaieb K, Hajlaoui H, Zmantar T, Nakbi KAB, Rouabhia M, Mahdouani K \& Bakhrouf A (2007). The chemical composition and biological activity of essential oil, Eugenia cryophyllata (SyzygiumaromaticumL. Myrtaceae): a short review. Phytother Res 21(6): 501506.

23. Santoyo S, Cavero S, Jaime L, Ibanez E, Senoransand F \& Reglero G (2005). Chemical composition and antimicrobial activity of Rosmarinus officinalis $L$. obtained via supercritical fluid extraction. J Food Prot 68(4): 790-795.

24. Sabahat S \& Perween T (2008). In vitro Antibacterial activity of Clove against Gram negative bacteria. Pak J Bot 40(5): 2157-2160.

25. Ceylan E \& Fung DYC (2004). Antimicrobial activity of spices. J Rapid Meth Aut Mic 12: 1-55.

26. Lopez-Malo VA, Palou E \& Alzamora SM (2005). Naturally occurring compounds plant sources. In P. M. Davidson, J. N. Sofos, \& A. L. Branen (Eds.), Antimicrobials in food (3rd ed., pp. 429-446). Boca Raton, Florida: CRC Press.

27. Duffy CF \& Power RF (2001). Antioxidant and antimicrobial properties of some Chinese plant extracts. Int J Antimicrob Agents 17: 527-529.

28. Bagamboula C F, Uyttendaele M \& Debevere J (2004). Inhibitory effect of thyme and basil essential oils, carvacrol, thymol, estragol, linalool and p-cimene 
towards Shigellasonnei and S. flexneri. Food Microbiol 21: 33-42.

29. Benkeblia N (2004). Antimicrobial activity of essential oil extracts of various onions (Allium cepa) and garlic (Allium sativum). LebensmittelWissenschaft and Technologie, 37: 263268.

30. Holley RA \& Patel D (2005). Improvement in shelf-life and safety of perishable foods by plant essential oils and smoke antimicrobials. Food Microbiol 22(4): 273-292.

31. Moreira MRA, Ponce G, de Valle CE \& Roura SI (2005). Inhibitory parameters of essential oils to reduce a foodborne pathogen. Lebensmittel-Wissenschaft and Technol 38: 565-570.

32. Menon VK and Garg SR (2001). Inhibitory effect of clove oil on Listeria monocytogenes in meat and cheese. Food Microbiol 18: 647-650.

33. Fisher K \& Phillips C (2006). The effect of lemon, orange and bergamot essential oils and their components on the survival of Campylobacter jejuni, Escherichia coli O157, Listeria monocytogenes, Bacillus cereus and Staphylococcus aureusin vitro and in food systems. J Appl Microbiol 101(6): 1232-1240. 